\title{
Synthesis and characterization of mixed ligand catecholato-bis (diamine-mono- dithiocarbamato) vanadium (IV) complexes
}

\author{
B. Begum ${ }^{1}$, A. Sarker ${ }^{1}$, A.K.M. Lutfor Rahman ${ }^{1 *}$ and N. C. Bhoumik ${ }^{2}$ \\ ${ }^{1}$ Jagannath University, Dhaka 1100, Bangladesh \\ ${ }^{2}$ Wazed Miah Science Research Centre, Jahangirnagar University, Dhaka-1342, Bangladesh
}

\begin{abstract}
Diamine-mono-dithiocarbamates are mono-basic bidentate ligand forming stable complexes with transition metals. Mixed ligand catecholato-bis (diamine-mono-dithiocarbamato) vanadium (IV) complexes were synthesized and characterized using FT-IR, UV-visible and ${ }^{1} \mathrm{H}$-NMR spectroscopic techniques. The formation of vanadium complexes was confirmed by the disappearance of $\mathrm{v}_{\mathrm{S}-\mathrm{H}}$ band in the complexes which was present in the ligands and incidence of $v_{\mathrm{v}-\mathrm{S}}$ and $\mathrm{v}_{\mathrm{v}-\mathrm{O}}$ band in FT-IR spectra of the complexes. The mono-dithiocarbamate with one uncoordinated $v_{\mathrm{NH} / \mathrm{NH} 2}$ group was indicated by the presence of $\mathrm{v}_{\mathrm{N}-\mathrm{H}}$ vibrational band in both the ligands and complexes. In the ${ }^{1} \mathrm{H}-\mathrm{NMR}$ spectra, the peak for $-\mathrm{SH}$ proton of ligands disappeared in the complexes suggest the formation of [VL $\mathrm{Cat}$ ] complex. Non-electrolytic nature of the synthesized complexes was established by their low molar conductance values. The +4 oxidation state of vanadium was confirmed by the electronic spectra of the complexes. On the basis of all physico-chemical data, a six-coordinated octahedral structure has been suggested for catecholato-bis (diamine-mono-dithiocarbamato) vanadium (IV) complexes.
\end{abstract}

Key words: Diamine-mono-dithiocarbamate-catechol mixed ligand; V(IV) complex; Molar conductance; FT-IR; Electronic and ${ }^{1} \mathrm{H}-\mathrm{NMR}$ spectra

\section{Introduction}

Dithiocarbamate (DTC) is a group of organosulphur chelating ligand that form a wide variety of stable complexes with interesting and quite novel properties and structures. Research on these compounds has drawn special attention because of their potential applications as high pressure lubricants in industry, medicines, fungicides and pesticides. In DTC and their complexes, sulphur donor atoms and extensive delocalized $\pi$ density act as a potential source of charge transfer intermolecular (weak) bonding. With o-donation and n-back-donation in the same order of magnitude through sulfur atoms of dithiocarbamate moiety, these ligands possess a special feature of additional n-electron flow from nitrogen to sulphur via a planar delocalized $\pi$ - orbital system (Nabipour et al., 2010). Krishnan et al. (2015) have synthesized cobalt (II) piperidine dithiocarbamate and diamines such as ethylene diamine, diethylene triamine and triethylene tetramaine $\left[\mathrm{Co}\right.$ (amine) (pmdtc) $\left.{ }_{2}\right]$ and observed considerable activity of the complexes as anticancer agents. Uddin et al. (2012) have synthesized dioxo-uranium complexes of diamine-mono-dithiocarbamate ligands $\left(\mathrm{UO}_{2} \mathrm{~L}_{2}\right)$, where diamines are ethylenediamine, N, N- dimethyl ethy lenediamine, $\mathrm{N}, \mathrm{N}$ - diethyl ethylenediamine, 1 , 3-propane diamine, $\mathrm{N}, \mathrm{N}$ - dibutyl-tri-methylene diamine, 1, 6- hexanediamine and reported their antifungal and antibacterial activity. Phenylmercury (II) methyl ferrocenyl dithiocarbamate having light harvesting properties as a photosensitizer in dye sensitized solar cells (DSSCs) has been synthesized by Chauhan et al. (2015).

The synthesis of catecholato-bis (diamine-monodithiocarbamato) vanadium (IV) complexes is totally a new approach. Vanadium is a biologically active metal.The interest in vanadium complex is due to their potential therapeutic and catalytic applications. Therefore, catecholato- bis (diamine-mono-dithiocarbamato) vanadium (IV) might become an effective catalyst as well as nontoxic metal antitumor, antifungal and antibacterial species.

\section{Materials and methods}

1, 3-propanediamine, $\mathrm{N}, \mathrm{N}^{\prime}$-diethyl ethylenediamine, 1 , 6-hexanediamine were obtained from SIGMA ALDRICH and carbon disulphide from E. Merck, Germany. Vanadium(IV) oxosulphate and catechol were purchased from Fisher Scientific Company, USA.

\footnotetext{
* Corresponding author e-mail: lrahman1973@gmail.com
} 
Dimethyl sulphoxide (DMSO) and petroleum spirit were collected from E. Merck, Germany, DMF from DAEJUNG, KOREA and nujol mull from Merck, India. Ethylenediamine, methanol and ethanol were used as supplied (Scharlau, Spain). All of the chemicals and solvents were analytical grade and were used directly without further purification.

The diamine-mono-dithiocarbamate ligands were synthesized by the usual condensation of diamine or their substituted diamine (having at least one $\mathrm{H}$-on amine group) with their same molar proportion of the carbon-disulphide $\left(\mathrm{CS}_{2}\right)$ (the type of $\left.\mathrm{R}_{2} \mathrm{~N}-\left(\mathrm{CH}_{2}\right)_{2}-\mathrm{NR}-\mathrm{CS}_{2}\right)$ by the published procedure (Chowdhury et al., 2006).

\section{Preparation of diamine-mono-dithiocarbamate ligands}

The diamine-mono-dithiocarbamate ligands $\left(\mathrm{R}_{2} \mathrm{~N}-\left(\mathrm{CH}_{2}\right)_{2}-\right.$ NR-CS ${ }_{2}$ ) were prepared by the condensation of equimolar proportion of diamine (having at least one $\mathrm{H}$ on amine group) with carbon-disulphide ( $\left.\mathrm{CS}_{2}\right)$. The solution of diamine viz. ethylenediamine, 1, 3- propanediamine, $\mathrm{N}$, $\mathrm{N}$-diethyl ethylenediamine and 1, 6- hexanediamine (each of $150 \mathrm{mmol}$ ) in $50 \mathrm{~mL}$ methanol was allowed to cool in a freezing mixture of ice and salt. To this solution, $\mathrm{CS}_{2}(140$ mmol, a bit less to protect the dimerization) was added drop-wise over a period of about half an hour with constant stirring until white precipitate was formed. The precipitate was allowed to stand for about 5 hours in the ice-salt bath, filtered, washed with methanol and dried over silica gel. The prepared ligands were ethylenediamine-monodithiocarbamate $\left(\mathrm{L}^{1}\right), \quad$ 1, 3-propanediamine-monodithiocarbamate $\left(\mathrm{L}^{2}\right), \quad \mathrm{N}, \quad \mathrm{N}$ - diethyl ethylene diamine-mono-dithiocarbamate $\left(\mathrm{L}^{3}\right)$ and 1, 6hexanediamine-mono-dithiocarbamate $\left(\mathrm{L}^{4}\right)$. The possible chemical reaction scheme is-<smiles>[R][C@@H](O)[C@@H](C)[B]N([R])CCN([R])[R]</smiles>

where $\mathrm{R}$ and $\mathrm{R}^{\prime}=\mathrm{H}, \mathrm{C}_{2} \mathrm{H}_{5}$

\section{Preparation of catecholato-bis (diamine-mono- dithiocarbamato) vanadium (IV) complexes}

For the synthesis of vanadium complexes, $1 \mathrm{mmol}$ each of vanadium(IV) oxosulphate, $\mathrm{VO}\left(\mathrm{SO}_{4}\right)$ and catechol were added to $2 \mathrm{mmol}$ diamine-mono-dithiocarbamate ligand solubilized in $50 \mathrm{~mL}$ water. This solution was refluxed for about 2 hours to get the dark green precipitate of complex which was then filtered off, washed with ethanol and finally dried over silica gel. Catecholato-bis (ethylenediamine-mono-dithiocarbamato)vanadium (IV)[VL ${ }^{1}$ Cat]), Catecholato-bis (1, 3-Propanediamine-monodithiocarbamato)vanadium(IV) $\left.\left[\mathrm{VL}^{2} \mathrm{Cat}\right]\right)$, Catecholato-bis (N,N'-diethyl- ethylenediamine-mono- dithiocarbamato) vanadium(IV) $\left.\left[\mathrm{VL}^{3} \mathrm{Cat}\right]\right)$ and Catecholato-bis (1,6hexanediamine- mono-dithiocarbamato) vanadium (IV) $\left.\left[\mathrm{VL}_{2}^{4} \mathrm{Cat}\right]\right)$ were prepared following the above procedure. The proposed chemical reaction scheme is-

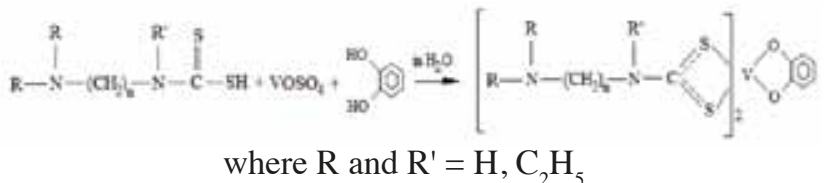

Melting points of the ligands as well as of the complexes were obtained with Melting Point apparatus; model KRUSS, KSPINN. The elemental analysis of the prepared ligands and complexes were performed by Elementar (Vario-EL cube) and metal analysis by Shimadzu AA-7000 AAS using GFA-7000. Conductivity measurements of the samples were done by a conductometer model CTS-406K using N, N-dimethyl-formamide (DMF) as solvent. The FT-IR spectra were recorded with FT-IR 8400S Shimadzu spectrophotometer in the range $400-4000 \mathrm{~cm}^{-1}$ at $2 \mathrm{~cm}^{-1}$ resolution and 30 times scanning using $\mathrm{KBr}$ as reference. ${ }^{1} \mathrm{H}-\mathrm{NMR}$ spectra were recorded on BRUKER $400 \mathrm{MHz}$ NMR spectrometer. Electronic absorption spectra for ligands and their vanadium (IV) complexes were run on a Shimadzu UV-Visible spectrophotometer (model-UV 1800) using $1 \mathrm{~cm}$ cell and were recorded in the medium of water, DMSO and paraffin (Nujol mull). Physical data of the prepared ligands and complexes are shown in Table I.

\section{Results and discussion}

\section{Elemental ( $C, H, N$ and $S)$ Analysis}

Elemental data of the prepared dithiocarbamate ligands and catecholato-bis (diamine-mono-dithiocarbamato) vanadium (IV) complexes are shown in Table I. From the elemental data, it is observed that there is a good agreement between experimental and calculated data which support the formation of vanadium complex.

\section{Molar Conductance measurement}

Molar Conductance was calculated by using the formula, $\Lambda$ $\mathrm{m}=1000 / \mathrm{C} \times$ cell const. $\times$ observed conductance. $10^{-3} \mathrm{M}$ solution was used for conductivity measurement.The molar conductance $\left(\Lambda_{\mathrm{m}}\right)$ values of the prepared catecholato-bis 
Table I. Physical, elemental and conductivity data for the diamine-mono-dithiocarbamate ligands and catecholato-bis (diamine-mono-dithiocarbamato) vanadium (IV) [VL2Cat] complexes

\begin{tabular}{|c|c|c|c|c|c|c|c|c|c|}
\hline \multirow{2}{*}{$\begin{array}{l}\text { Ligand } \\
\text { /Complex }\end{array}$} & \multicolumn{4}{|c|}{ Physical data } & \multicolumn{4}{|c|}{ Elemental analysis } & \multirow{2}{*}{$\begin{array}{l}\text { Conductivity data } \\
\text { Molar conductance } \\
(\Lambda \mathrm{m}) \text { ohm }{ }^{-1} \mathrm{~cm}^{2} \mathrm{~mol}^{-1} \\
\text { (Solvent: DMF) }\end{array}$} \\
\hline & Colour & $\begin{array}{c}\text { Yield } \\
\%\end{array}$ & $\begin{array}{l}\text { m.p. } \\
\left({ }^{\mathrm{o}} \mathrm{C}\right)\end{array}$ & $\begin{array}{l}\mathrm{C} \% \\
(\mathrm{Cal})\end{array}$ & $\begin{array}{l}\mathrm{H} \% \\
(\mathrm{Cal})\end{array}$ & $\begin{array}{c}\mathrm{S} \% \\
(\mathrm{Cal})\end{array}$ & $\begin{array}{l}\mathrm{N} \% \\
(\mathrm{Cal})\end{array}$ & $\begin{array}{l}\mathrm{V} \% \\
(\mathrm{Cal})\end{array}$ & \\
\hline $\mathrm{L}^{1}$ & White & 87 & 184 & $\begin{array}{l}(26.0) \\
(26.5)\end{array}$ & $\begin{array}{l}(5.1) \\
(5.9)\end{array}$ & $\begin{array}{c}47.0 \\
(47.5)\end{array}$ & $\begin{array}{c}20 \\
(20.6)\end{array}$ & -- & -- \\
\hline $\mathrm{L}^{2}$ & White & 84 & 134 & $\begin{array}{c}32.2 \\
(32.0)\end{array}$ & $\begin{array}{c}6.5 \\
(6.7)\end{array}$ & $\begin{array}{c}42.2 \\
(42.7)\end{array}$ & $\begin{array}{c}18 \\
(18.7)\end{array}$ & -- & -- \\
\hline $\mathrm{L}^{3}$ & White & 85 & 139 & $\begin{array}{c}44.1 \\
(43.8)\end{array}$ & $\begin{array}{c}7.9 \\
(8.3)\end{array}$ & $\begin{array}{c}32.7 \\
(33.3)\end{array}$ & $\begin{array}{c}14.7 \\
(14.6)\end{array}$ & -- & -- \\
\hline$L^{4}$ & White & 82 & 137 & $\begin{array}{c}44.1 \\
(43.8)\end{array}$ & $\begin{array}{c}7.4 \\
(8.3)\end{array}$ & $\begin{array}{c}34.0 \\
(33.3)\end{array}$ & $\begin{array}{c}14.6 \\
(14.6)\end{array}$ & -- & -- \\
\hline $\mathrm{VL}_{2}{ }_{2} \mathrm{Cat}$ & Black & 82 & $>230$ & $\begin{array}{c}32.8 \\
(33.4)\end{array}$ & $\begin{array}{c}3.8 \\
(4.6)\end{array}$ & $\begin{array}{c}28.0 \\
(29.7)\end{array}$ & -- & $\begin{array}{c}10.2 \\
(11.8)\end{array}$ & 6.7 \\
\hline $\mathrm{VL}_{2}^{2} \mathrm{C}$ & Black & 80 & $>220$ & $\begin{array}{c}35.5 \\
(36.7)\end{array}$ & $\begin{array}{c}4.0 \\
(4.8)\end{array}$ & $\begin{array}{c}27.6 \\
(28.0)\end{array}$ & -- & $\begin{array}{c}9.8 \\
(10.9)\end{array}$ & 7.8 \\
\hline $\mathrm{VL}_{2}^{3} \mathrm{Cat}$ & Black & 81 & $>220$ & $\begin{array}{c}39.8 \\
(41.7)\end{array}$ & $\begin{array}{c}5.8 \\
(6.5)\end{array}$ & $\begin{array}{c}23.8 \\
(24.7)\end{array}$ & -- & $\begin{array}{c}8.5 \\
(9.8)\end{array}$ & 5.7 \\
\hline $\mathrm{VL}_{2}^{4} \mathrm{Cat}$ & Black & 80 & $>220$ & $\begin{array}{c}39.2 \\
(40.1)\end{array}$ & $\begin{array}{c}5.5 \\
(6.1)\end{array}$ & $\begin{array}{c}23.6 \\
(24.2)\end{array}$ & -- & $\begin{array}{c}8.7 \\
(9.4)\end{array}$ & 6.5 \\
\hline
\end{tabular}

(diamine-mono-dithiocarbamato) vanadium (IV) complexes were carefully determined as a function of their concentration in a very dilute solution of DMF at $30^{\circ} \mathrm{C}$. Observed $\Lambda_{\mathrm{m}}$ values of the complexes are shown in Table I. The molar conductance of the complexes is in the range of 5.7-7.8 $\mathrm{ohm}^{-1} \mathrm{~cm}^{2} \mathrm{~mol}^{-1}$ which is very low. The low molar conductivity values of all the prepared complexes revealed them to be essentially non-electrolyte (Geary, 1971). Thus, the observed low molar conductance is good evidence in support of the formation of catecholato-bis (diamine-mono-dithiocarbamato) vanadium (IV) complexes through $\mathrm{V}^{4+}$ cation and mono basic nature of the coordinated diamine-mono-dithiocarbamate ligand.
FT-IR spectra

The bonding and structural properties of metal complexes were characterized by infrared studies. Dithiocarbamate possesses $v_{\mathrm{C}-\mathrm{N}}$ band at $1370-1410 \mathrm{~cm}^{-1}$ (Percy et al., 1976), $v_{\mathrm{C}=\mathrm{S}}$ (thioketo) band at $1104-1200 \mathrm{~cm}^{-1}$ and $v_{\mathrm{C}-\mathrm{S}}$ (thiolato) band at $760 \mathrm{~cm}^{-1}$ reported by Onwudiwe et al. (2011) and Jayasree et al. (1993). The infrared spectra of the free ligands exhibit medium intense band at $2550 \mathrm{~cm}^{-1}$ for $v_{\mathrm{S}-\mathrm{H}}$ and 3150-3300 $\mathrm{cm}^{-1}$ for $\mathrm{v}_{\mathrm{N}-\mathrm{H} / \mathrm{NH}_{2}}$ observed by Chowdhury et al. (2006). Strong bands at $1575-1600 \mathrm{~cm}^{-1}$ and $1500 \mathrm{~cm}^{-1}$ were recognized by Sharma (1989) for the $\delta_{\mathrm{N}-\mathrm{H}}$ vibrations in the amino salts. In the case of dithiocarbamate 
ligand two bands at $960-1020 \mathrm{~cm}^{-1}$ were due to the asymmetric $v_{\text {CSS }}$ mode stated by Yin et al. (2008). It was anticipated that the presence of a single band at $1000 \mathrm{~cm}^{-1}$ region is the characteristic bidentate nature for the dithiocarbamate moiety in the complex, while the splitting of the same band within a difference of $20 \mathrm{~cm}^{-1}$ in the same region is due to the mono-dentate binding of dithiocarbamate ligand (Nami et al., 2004). A strong band was observed in the region of 500-600 $\mathrm{cm}^{-1}$ for V-O absorption in the V(IV) complex ( Mishra et al., 2012). The band at $980-990 \mathrm{~cm}^{-1}$ was attributed to the stretching vibration of the terminal $\mathrm{V}=\mathrm{O}$ bond in the complex (Mishra et al., 2005). The bands appeared in the region $617-670 \mathrm{~cm}^{-1}$ were assigned as $v_{\mathrm{M}-\mathrm{S}}$ (thiol) stretching modes and the bands in the region $408-555 \mathrm{~cm}^{-1}$ were assigned as $\mathrm{v}_{\mathrm{M}-\mathrm{S}}$ (thioketo) vibrations (where, $\mathrm{M}$ indicate the central metal atom) (Chowdhury et al., 2006; Sainorudin et al., 2015; Sutriah et al., 2014).
In the present study, the FT-IR data of all diamine-mono-dithiocarbamate ligands and their complexes are listed in Table II. The main stretching modes observed in the complexes are $v_{\mathrm{NH} / \mathrm{NH} 2,} \mathrm{v}_{\mathrm{C}-\mathrm{N}}, \mathrm{v}_{\mathrm{C}-\mathrm{S}}$, $v_{\text {CSS }}$ and $v_{S-H}$. The $v_{S-H}$ band for ligands disappeared in the IR spectra of the complexes while no significant change noticed for $\mathrm{U}_{\mathrm{N}-\mathrm{H} / \mathrm{NH}_{2}}$ modes. These indicate that the bonding taking place through the sulphur atom only and amino group in the ligand is not involved in the complexation. Ligands show FT-IR bands at $984-1030$ $\mathrm{cm}^{-1}$ due to $v_{\mathrm{CSS}}$ mode (Yin et al., 2008). But in the same region the presence of strong single band for all of the prepared complexes indicate that dithiocarbamate moiety is symmetrically coordinated to the metal ion (Johnson et al., 1969) and show bi-dentate behavior.

Table II. Infrared spectral data of different diamine-mono-dithiocarbamate ligands and catecholato-bis (diaminemono-dithiocarbamato) vanadium (IV) [VL2Cat] complexes

\begin{tabular}{|c|c|c|c|c|c|c|c|c|}
\hline \multirow{2}{*}{$\begin{array}{l}\text { Bands } \\
\left(\mathrm{cm}^{-1}\right)\end{array}$} & \multicolumn{5}{|c|}{ Ligands } & \multicolumn{3}{|l|}{ Complexes } \\
\hline & $\mathrm{L}^{1}$ & $\mathrm{~L}^{2}$ & $\mathrm{~L}^{3}$ & $\mathrm{~L}^{4}$ & {$\left[\mathrm{VL}_{2}{ }_{2} \mathrm{Cat}\right]$} & {$\left[\mathrm{VL}_{2}^{2} \mathrm{Cat}\right]$} & {$\left[\mathrm{VL}_{2}{ }_{2} \mathrm{Cat}\right]$} & {$\left[\mathrm{VL}_{2}^{4} \mathrm{Cat}\right]$} \\
\hline $\bar{v} \mathrm{NH} / \mathrm{NH} 2$ & 3240 & 3311 & 3200 & 3160 & 3183 & 3435 & 3431 & 3416 \\
\hline$\delta \mathrm{NH} 2$ & 1517 & 1557 & 1520 & 1535 & --- & --- & --- & --- \\
\hline $\bar{v} \mathrm{C}=\mathrm{S}$ & 1205 & 1205 & 1200 & 1208 & 1118 & 1112 & 1114 & 1126 \\
\hline $\bar{v} \mathrm{C}-\mathrm{S}$ & 745 & 760 & 750 & 740 & 812 & 802 & 799 & 816 \\
\hline $\bar{v} \mathrm{CSS}$ & 1001 & 1032 & 1040 & 1030 & 1031 & 1045 & 1029 & 1031 \\
\hline $\bar{v} \mathrm{C}-\mathrm{N}$ & 1351 & 1364 & 1350 & 1345 & 1323 & 1315 & 1391 & 1363 \\
\hline $\bar{v} \mathrm{~S}-\mathrm{H}$ & 2571 & 2570 & 2530 & 2570 & --- & --- & --- & --- \\
\hline $\bar{v} \mathrm{C}-\mathrm{O}$ & --- & --- & --- & --- & 1269 & 1265 & 1254 & 1261 \\
\hline \multirow[t]{2}{*}{$\bar{v} \mathrm{~V}-\mathrm{S}$} & --- & --- & --- & --- & 399(keto) & 418(keto) & 420 (keto) & 432(keto) \\
\hline & & & & & $653(\mathrm{ol})$ & $618(\mathrm{ol})$ & $610(\mathrm{ol})$ & $630(\mathrm{ol})$ \\
\hline $\bar{v} \mathrm{~V}-\mathrm{O}$ & --- & --- & --- & --- & 601 & 600 & 526 & 615 \\
\hline
\end{tabular}


The band at $\sim 1200 \mathrm{~cm}^{-1}$ assigned for $v_{\mathrm{C}=\mathrm{S}}$ shifted by about $80-90 \mathrm{~cm}^{-1}$ to a lower wave number in the case of complexes indicate the involvement of the thioketo sulphur in coordination. The absence of any band around $2550 \mathrm{~cm}^{-1}$ in the prepared complexes (which was present in the ligand) indicates the de-protonation of the thiol group due to coordination. The band, $v_{\mathrm{C}-\mathrm{S}}$ at $\sim 760 \mathrm{~cm}^{-1}$ shifted by about $\sim 40 \mathrm{~cm}^{-1}$ to a higher energy due to coordination through sulphur atom. The $v_{\mathrm{C}-\mathrm{S}}$ (thiolato) shifted to higher energy due to the maintenance of a ring current arising for electron delocalization in a chelate ring. The presence of $v_{\mathrm{V}-\mathrm{S}}$ thiolato

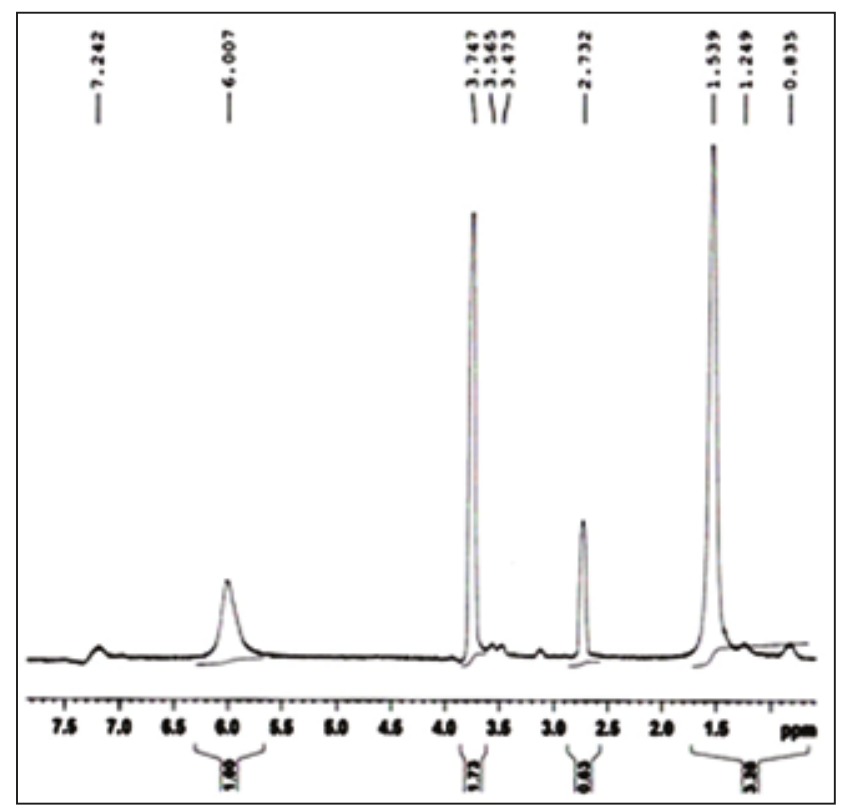

Fig. 1. ${ }^{1} \mathrm{H}$ NMR Spectrum of $\mathrm{L}^{1}$ ligand

and $v_{\mathrm{V}-\mathrm{S}}$ thioketo and the disappearance of $v_{\mathrm{S}-\mathrm{H}}$ vibrations confirmed the coordination of $\mathrm{S}$ atoms to the metal ion and the monobasic nature of the ligands.

Chowdhury et al. (1998) observed the $v_{\mathrm{C}-\mathrm{O}}$ band at 1250-1260 $\mathrm{cm}^{-1}$ for the mono-dithiocarbamate and catecholate mixed ligand complexes of Ti (IV). Thus the band appeared at $1254-1269 \mathrm{~cm}^{-1}$ in the present mixed ligand $\mathrm{V}(\mathrm{IV})$ complexes designate the $v_{\mathrm{C}-\mathrm{O}}$ vibration. The presence of $v_{\mathrm{C}-\mathrm{O}}$ mode at $\sim 1254-1269 \mathrm{~cm}^{-1}$ and $v_{\mathrm{V}-\mathrm{O}}$ mode at $526-601 \mathrm{~cm}^{-1}$ in the FT-IR spectra revealed the coordination of catechol with vanadium along with diamine-mono-dithiocarbamate ligands.

\section{${ }^{1} H$ NMR spectra}

The ${ }^{1} \mathrm{HNMR}$ spectra of ligandL ${ }^{1}$ and complex [VL ${ }_{2}^{1} \mathrm{Cat}$ ] were taken dissolving in DMSO solvent and are shown in Fig. 1 and 2, respectively. It was reported that the protons for $>\mathrm{CH}_{2}$ group has chemical shift in the range $\delta=$ 1.43-1.54 ppm (Oliveira et al. 1999). The peak in the region 3.82-3.64 ppm for the protons of $-\mathrm{NH}_{2}$ group was ascribed by Onwudiwe (2011). In both of the prepared ligand and $\mathrm{V}(\mathrm{IV})$ complex, $>\mathrm{CH}_{2}$ protons observed at $\delta=1.539$ and $\delta$ $=1.560 \mathrm{ppm}$, respectively. The presence of $-\mathrm{SH}$ proton at $2.732 \mathrm{ppm}$ in the ligand (Nabipour, 2011)and absence of this peak in the spectra of the respective complex suggested the coordination between ligand and metal through the $\mathrm{S}$ moiety.Peak at $3.747 \mathrm{ppm}$ and $3.750 \mathrm{ppm}$ in both the spectra

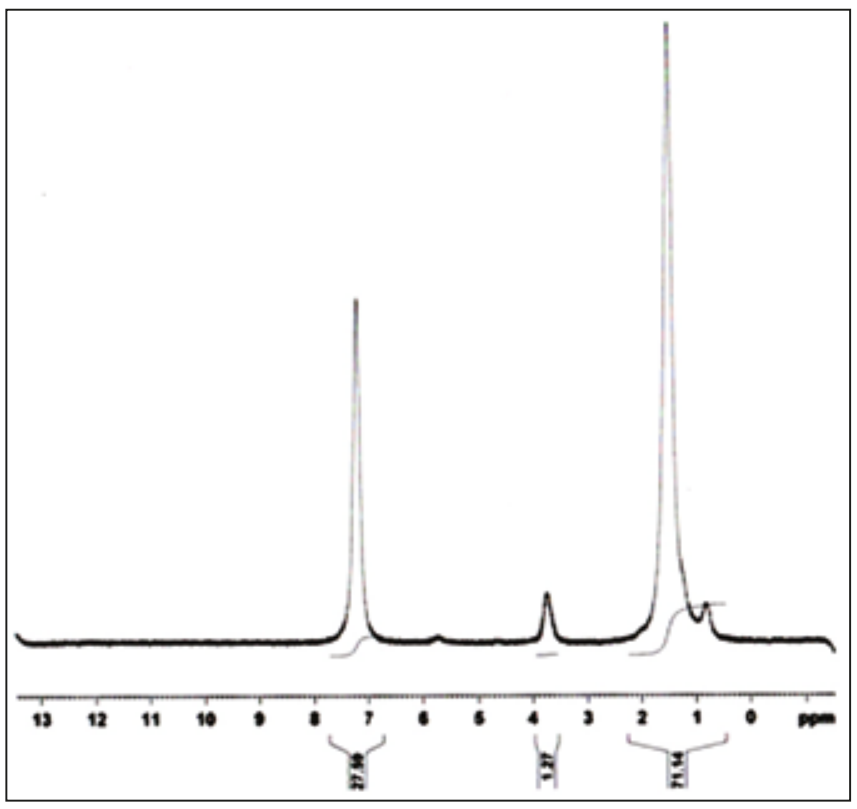

Fig. 2. ${ }^{1} \mathrm{H}$ NMR Spectrum of $\left[\mathrm{VL}^{1}{ }_{2} \mathrm{Cat}\right]$ complex

of the prepared ligand and complex, respectively indicate the presence of $-\mathrm{NH}_{2}$.

In the ${ }^{1} \mathrm{HNMR}$ spectrum of $\mathrm{L}^{1}$, the peak at $6.007 \mathrm{ppm}$ corresponds to the proton of $>\mathrm{NH}$ was hardly seen in the spectra ofthe complex. This could be explained as with the same order o-donation and n-back-donation characteristics in sulphur atom of dithiocarbamate. This type ligand has an additional n-electron flow from nitrogen to sulphur via a planar delocalized $\pi$ - orbital system (Nabipour et al., 2010).

The proton for the phenyl groups exhibit chemical shifts in the range 7.27 - $8.07 \mathrm{ppm}$ due to deshielding on complexation reported by Yin et al. (2004). In the present $\mathrm{V}$ (IV) mixed ligand complex, peak is observed at $\delta=7.250$ ppm, which indicate that catechol coordinate with vanadium. ${ }^{1} \mathrm{H}$ NMR data for ethylene 
Table III. ${ }^{1} \mathrm{H}$ NMR data for ethylene diamine-mono-dithiocarbamate ligand, $\mathrm{L}_{1}$ and its complex [VL $\left.{ }_{2}{ }_{2} \mathrm{Cat}\right]$

\begin{tabular}{lllll}
\hline Compounds & $\begin{array}{l}>\mathrm{CH}_{2} \text { protons } \\
\delta \mathrm{ppm}\end{array}$ & $\begin{array}{l}-\mathrm{NH}_{2} \text { protons } \\
\delta \mathrm{ppm}\end{array}$ & $\begin{array}{l}-\mathrm{SH} \text { protons } \\
\delta \mathrm{ppm}\end{array}$ & $\begin{array}{l}\text { phenyl protons } \\
\delta \mathrm{ppm}\end{array}$ \\
\hline $\mathrm{L}_{1}$ & $1.539(2 \mathrm{H})$ & $3.747(2 \mathrm{H})$ & $2.732(\mathrm{H})$ & -- \\
{$\left[\mathrm{VL}_{2} \mathrm{Cat}\right]$} & $1.560(2 \mathrm{H})$ & $3.750(2 \mathrm{H})$ & --- & $7.250(4 \mathrm{H})$ \\
\hline
\end{tabular}

Table IV. Electronic spectral data for the diamine-mono-dithiocarbamate ligands and catecholato-bis (diaminemono-dithiocarbamato) vanadium (IV) $\left[\mathrm{VL}_{2} \mathrm{Cat}\right]$ complexes

\begin{tabular}{|c|c|c|c|c|c|}
\hline Ligands Medium & \multicolumn{2}{|c|}{ Bands (nm) } & Complexes & Medium & Bands (nm) \\
\hline $\mathrm{L}^{1}$ & Water & $269.9,367.7$ & {$\left[\mathrm{VL}_{2}{ }_{2} \mathrm{Cat}\right]$} & DMSO & 252,268 \\
\hline $\mathrm{L}^{2}$ & DMSO & $250,265,300$ & {$\left[\mathrm{VL}_{2}^{2} \mathrm{Cat}\right]$} & DMSO & 263 \\
\hline $\mathrm{L}^{3}$ & DMSO & $250,260,305$ & {$\left[\mathrm{VL}^{3}{ }_{2} \mathrm{Cat}\right]$} & NM & 236 \\
\hline $\mathrm{L}^{4}$ & DMSO & $260,300,367$ & {$\left[\mathrm{VL}_{2}^{4} \mathrm{Cat}\right]$} & NM & 234 \\
\hline
\end{tabular}

diamine-mono-dithiocarbamate ligand, $\mathrm{L}_{1}$ and its complex $\left[\mathrm{VL}_{2}{ }_{2} \mathrm{Cat}\right]$ are plotted in the Table III.

\section{Electronic spectra}

The region of the UV-visible bands of ligands and complexes are listed in Table IV. From the data of the complexes, it is observed that all the vanadium (IV) complexes have band at $234-268 \mathrm{~nm}$ correspond to $\pi-\pi^{*}$ transition in the near ultraviolet region. Transition for $\pi-\pi^{*}$ observed at $250-367 \mathrm{~nm}$ in all the prepared ligands. In the case of ' $d$ electron'system, absorption band for ${ }^{2} \mathrm{~T}_{2 \mathrm{~g}} \rightarrow{ }^{2} \mathrm{E}_{\mathrm{g}}$ transition might be expected at 500nm (Atkins et al., 2006), but in the present complexes, there were no absorption band for ${ }^{2} \mathrm{~T}_{2 \mathrm{~g}} \rightarrow{ }^{2} \mathrm{E}_{\mathrm{g}}$ transition. This is because, according to selection rule if $\pi$-acceptor and $\pi$-donor ligands can mix with the d-orbital then $d$ - $d$ transitions are no longer purely $\mathrm{d}-\mathrm{d}$.

\section{Conclusion}

Diamine mono-dithiocarbamate ligands were synthesized and found monobasic bidentate in nature. The prepared catecholato-bis-diamine-mono-dithiocarbamato vanadium
(IV) complexes were found to be of the type [ $\left.\mathrm{VL}_{2} \mathrm{Cat}\right]$. Analytical data indicated that the complexes were $1: 2: 1$ (metal:ligand:catechol) stoichiometry. Non-electrolytic nature of the prepared mixed ligand complexes was confirmed by conductance study. The presence of $\mathrm{V}-\mathrm{S}$ thiolato and $\mathrm{V}-\mathrm{S}$ thioketo and the disappearance of $v_{\mathrm{S}-\mathrm{H}}$ vibrations confirmed the coordination of $\mathrm{S}$ donor atoms of the ligands to the metal ion and the monobasic nature of the ligands. The shifts of $v_{\mathrm{C}=\mathrm{S}}$ bands to the lower wave number and shifts of $v_{\mathrm{C}-\mathrm{S}}$ bands to higher wave number in the IR spectra of the prepared mixed ligand complexes also suggested the bonding of ligands with $\mathrm{V}^{4+}$ ion through its thiocarbonyl and thioenolic sulphur atoms, thus enabling the ligands to act as bi-dentate one. The presence of $v_{\mathrm{C}-\mathrm{O}}$ and $\mathrm{v}_{\mathrm{V}-\mathrm{O}}$ modes in the IR spectra of the present mixed ligand complexes revealed the coordination of catechol with vanadium(IV).In the NMR spectra, the presence of $-\mathrm{SH}$ proton at $2.732 \mathrm{ppm}$ in the ligand and absence in the spectra of complex suggested the formation of [ $\left.\mathrm{VL}_{2} \mathrm{Cat}\right]$ complex. The $\left[\mathrm{V}\left(\mathrm{L}_{2}\right) \mathrm{Cat}\right]$ complexes are supposed to possess an octahedral structure. However, it is difficult to suggest the 
exact geometry of $\mathrm{V}\left(\mathrm{L}_{2}\right)$ Cat complex without crystal structure determination. Therefore, further study is necessary to establish the exact structure of the prepared complexes and the reaction mechanism.

\section{Acknowledgement}

We gratefully acknowledge Wazed Miah Science Research Center, Jahangirnagar University, Savar, Dhaka for providing elemental analysis, FT-IR and NMR spectra. We also acknowledge Centre for Advanced Research in Sciences(CARS), University of Dhaka for giving support of FT-IR spectra. Recognition goes to Jagannath University Development Project for financial support and the Department of Chemistry, Jagannath University, Dhaka for laboratory and other support.

\section{References}

Atkins P, Overton T, Rourke J, Weller M, Armstrong F, Paul S, Hagerman M and Spiro T (2006), Shriver and Atkins Inorganic Chemistry, $4^{\text {th }}$ Edn, W.H. Freeman and Company, New York, p 478.

Chauhan R, Kociok-Köhn G, Trivedi M, Singh S, Kumar A and Amalanerkar PD (2015), Phenylmercury(II) methylferrocenyldithiocarbamate-funtionalized dye-sensitized solar cells hydroxyl as an anchoring group, J. Solid State Electrochem. 19: 739-747.

Chowdhury AD and Uddin NM (1998), Some mixed-ligand complexes of Titanium (IV) containing mono-dithiocarbamates as the primary ligands, Bull. Pure Appl. Sci. 17C(2): 57-60.

Chowdhury AD, Uddin NM and Rahman LMKA (2006), Synthesis and Characterization of Dioxo-molybdenum (VI) Complexes of Some Dithiocarbamates, Chiang Mai J. Sci. 33(3): 357362.

Geary WJ (1971), The use of conductivity measurements in organic solvents for the characterisation of coordination compounds, Coord. Chem. Rev. 7(1): 81-122.

Johnson BFG, Al-Obalidi KH and Mecleverty JA, (1969), Transition-metal nitrosyl compounds. Part III. (NN-dialkyldithiocarbamato)nitrosyl compounds of molybdenum and tungsten, J. Am. Chem. Soc. A. 19: 1668-1670.

Jayasree S and Aravindakshan KK (1993), Synthesis, characterization and antitumour studies of metal chelates of acetoacetanilidethiosemicarbazone, Trans. Met. Chem. 18(1): 85-88.
Krishnan B and Vijayanthimala R (2015), Synthesis, characterisation and biological applications of mixed ligand cobalt (II) complexes containing Dithiocarbamates and Diamines, Int. J. Chem. Pharm.Sci.6(1): 36-40.

Mishra AP and Pandey LR (2005), Synthesis, characterization and solid state structural studies of oxovanadium (IV) - O, N donor Schiff base chelates, Indian J Chem. 44A: 94-97.

Mishra AP, Pandey LR and Jain KR (2012), Microwave Synthesis, Reactivity, Spectral and Thermal Analysis of Some Binary/Mixed Ligand Oxovanadium(IV) Complexes, Chem. Sci. Trans. 1(1): 121-133.

Nabipour H, Ghammamy S, Ashuri S and Aghbolagh SZ (2010), Synthesis of a New Dithiocarbamate Compound and Study of Its Biological Properties, Org. Chem. J. 2: 75-80.

Nabipour H (2011), Synthesis of a new dithiocarbamate cobalt complex and its nanoparticles with the study of their biological properties, Int. J. Nano. Dim. 1(3): 225-232.

Nami SAA and Siddiqi KS (2004), Convenient one-pot synthesis of symmetrical dithiocarbamates, Synth. React. Inorg. Met.-Org. Chem. 34(9): 1581-1590.

Oliveira MM, Pessoa GM, Carvalho LC, Peppe C, Souza A G and Airoldi C (1999), N, N-Dialkyldithiocarbamate chelates of indium (III): alternative synthetic routes and thermodynamics characterization, Thermochim. Acta 328(1-2): 223-230.

Onwudiwe CD and Ajibade AP (2011), Synthesis, Characterization and Thermal Studies of $\mathrm{Zn}(\mathrm{II})$, $\mathrm{Cd}(\mathrm{II})$ and $\mathrm{Hg}(\mathrm{II})$ Complexes of N-Methyl-N-Phenyldithiocarbamate: The Single Crystal Structure of $\left[\left(\mathrm{C}_{6} \mathrm{H}_{5}\right)\left(\mathrm{CH}_{3}\right) \mathrm{NCS}_{2}\right]_{4} \mathrm{Hg}_{2}$, Int. $J$. Mol.Sci. 12: 1964-1978.

Percy GC and Stenton HS (1976), Infrared and electronic spectra of $\mathrm{N}$-salicylideneglycinate complexes of cobalt and nickel, Spectrochim.Acta (A) Mol. Spectro. 32(10): 1615-1621.

Sainorudin HM, Sidek MN, Ismail N, Rozaini1 HZM, Harun AN, Anuart SNT, Azmi RAAA and Yusoff F (2015), Synthesis, Characterization and Biological Activity of Organotin (IV) Complexes featuring di-2-ethylhexyldithiocarbamate and $\mathrm{N}$-methylbutyldithiocarbamate as Ligands, GSTF J. Chem. Sci. 2(1): 10-18. 
Sharma YR.(1989), Elementary Organic Spectroscopy, $2^{\text {nd }}$ Ed., New Delhi, p 120.

Sutriah K, Mas'ud A Z, Irawadi TT and Khotib M (2014), Performance of Zinc-Difattyalkyldithiocarbamate as Anti-friction/Anti-wear Lubricant Additive, Indo. J. Chem. 14(1): 78 - 84 .

Uddin NM, Chowdhury AD, Islam TM and Hoque F (2012), Evaluation of biological activity of dioxouranium complexes of some Schiff base and dithiocarbamate ligands, Orbital Elec. J. Chem. Campo Grande 4(4): 273-287.

Yin HD, Zhai J, Sun YY and Wang DQ (2008), Synthesis, characterizations and crystal structures of new antimony (III) complexes with dithiocarbamate ligands, Polyhedron 27: 663-670.
Yin H, Wang C and Xing Q (2004), Synthesis and characterization of triphenyltin esters of heteroaromatic carboxylic acids and the crystal structure of $\left[\mathrm{Ph}_{3} \mathrm{SnO}_{2} \mathrm{CC}_{5} \mathrm{H}_{4} \mathrm{~N} \cdot 0.5 \mathrm{H}_{2} \mathrm{O}\right]$, Polyhedron 23(10): 1805-1810.

Received: 18 September 2016; Revised: 19 December 2016; Accepted: 28 December 2016. 